\title{
A Rare Cause of Acute Abdomen: Stump Appendicitis after Laparoscopic Appendectomy
}

\author{
- Serdar Aslan,' ๑ Mehmet Cihat Özek²
}

\author{
'Department of Radiology, Giresun \\ University Faculty of Medicine \\ Giresun, Turkey \\ ${ }^{2}$ Department of General Surgery, \\ Turhal State Hospital, Tokat, Turkey \\ Submitted: 30.03 .2019 \\ Accepted: 19.08.2019 \\ Correspondence: Serdar Aslan \\ Giresun Üniversitesi Tıp Fakültesi, \\ Radyoloji Anabilim Dalı, \\ Giresun, Turkey \\ E-mail: serdaraslan28@hotmail.com

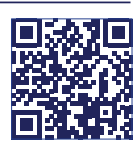 \\ Keywords: Acute \\ abdomen; appendectomy; \\ stump appendicitis. \\ This work is licensed under a Creative Commons \\ Attribution-NonCommercial 4.0 International License.
}

\begin{abstract}
Stump appendicitis is a rare complication of an appendiceal inflammation after an incomplete appendectomy. Diagnosis of stump appendicitis in patients who have a history of appendectomy and presenting with acute abdomen is frequently overlooked. Imaging methods are of great importance in diagnosis. In this case report, we aimed to present the imaging and operation findings of stump appendicitis with a history of right lower quadrant pain for two days and a history of laparoscopic appendectomy three months ago. The patient was discharged uneventfully following a stump appendectomy.
\end{abstract}

\section{INTRODUCTION}

Acute appendicitis is the most common surgical cause of acute abdomen. ${ }^{[l]}$ Rarely, complications, such as wound infection, brid ileus, intraabdominal abscess, and appendix stump leak, may be seen after the appendectomy. Stump appendicitis is quite rarely seen; it is the inflammation of the remaining appendix after the incomplete appendectomy. Acute appendicitis was first described by Rose in 1945 and its frequency was reported to be approximately $1 / 50000{ }^{[2]}$ There are around 60 cases reported in the literature until now. ${ }^{[3]}$ Stump appendicitis frequently presents with an acute abdomen, and the presence of appendectomy in the patient makes the diagnosis difficult and causes an increase in morbidity. ${ }^{[4]}$ Imaging methods are of considerable importance in diagnosis. In this case report, we aimed to present the findings of imaging and operation of the stump appendicitis who presented to the emergency department with right lower quadrant pain for two days with a history of laparoscopic appendectomy three months ago.

\section{CASE REPORT}

A 23-year-old female patient was admitted to the emergency department of our hospital with a 48-hour history of abdominal pain that had started in the periumbilical area, then localized at the right lower quadrant (RLQ), followed by nausea and vomiting. Three months earlier, she had undergone a laparoscopic appendectomy due to appendicitis. On physical examination, her body temperature was 37.8 degrees (axillary), and she had defense and rebound in the RLQ. Heel drop jarring test was positive. Laboratory examination revealed a white blood cell count (WBC) was 12,350 cells $/ \mathrm{mm}^{3}$ with $87 \%$ neutrophils, and C-reactive protein (CRP) was $4.5 \mathrm{mg} / \mathrm{dl}$. Urine analysis was normal. There was no abnormality in the chest X-ray and plain abdominal X-ray. Abdominal ultrasonography (USG) showed a $30 \mathrm{~mm}$ length, a peristaltic tubular structure with a diameter of $13 \mathrm{~mm}$ related to the cecum in the RLQ. There was an echogenic formation in the tubular structure, which was thought to be $16 \mathrm{~mm}$ length operative material. The pericecal mesenteric adipose tissue was highly pol- 

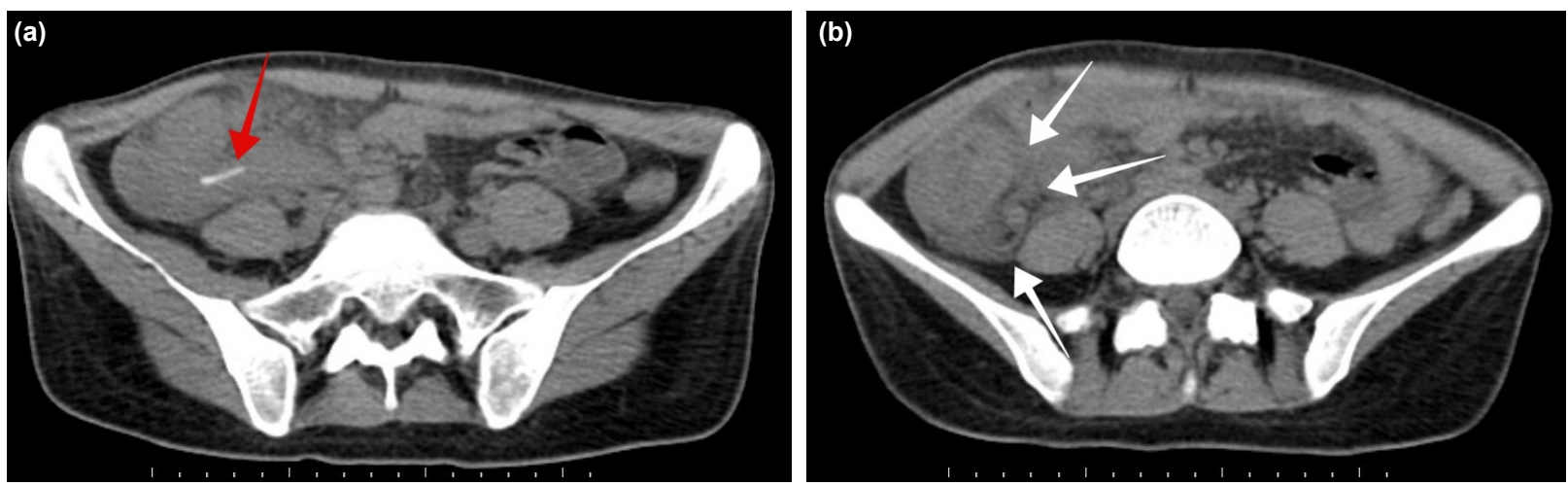

Figure 1. (a, b) On axial abdominopelvic CT image shows enlarged stump appendicitis (red arrow) with echogenic material, diffuse inflammatory changes and fluid values in the pericecal area (white arrows).

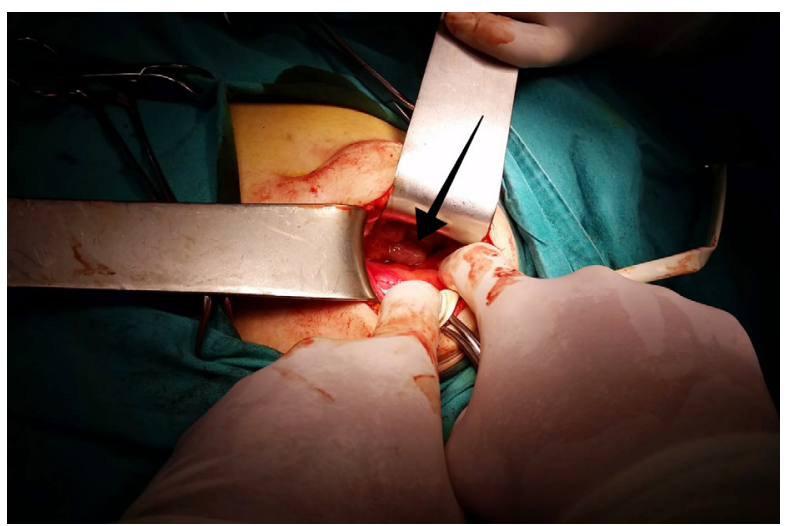

Figure 2. On intraoperative image show that stump appendicitis is observed as enlarged and inflamed (black arrow).

luted and the non-loculated fluid collections were seen. On abdominopelvic computed tomography (CT), similar to USG, with an echogenic formation inside it, approximately $30 \mathrm{~mm}$ length tubular structure associated with the cecum, free fluid collections and linear inflammatory changes were observed in the pericecal area (Fig. Ia, b). Stump appendicitis was considered in the patient who had a history of appendectomy with the present findings and the patient was taken into operation for a complementary appendectomy. The abdomen was entered using McBurney incision. Purulent fluid and severe adhesions in the right iliac fossa were observed. After aspiration and adhesiolysis, approximately $3 \mathrm{~cm}$ length appendiceal stump was observed at the associated with the distal cecum (Fig. 2). Stump appendectomy was performed and the operation was completed. Placement of a rubber drain inside the abdomen was not considered necessary. The postoperative period was uneventful and the patient was discharged on the fifth postoperative day. Written informed consent was obtained from the patient for publishing this case.

\section{DISCUSSION}

Stump appendicitis is a rare complication following an appendectomy. Although the incidence has been reported as $1 / 50000$ in the literature, its incidence has increased in recent years. This is thought to be due to an increase in the number of laparoscopic appendectomies. ${ }^{[5]}$ During a laparoscopic appendectomy, residual a long stump due to insufficient dissection can act as a reservoir for fecalith and may cause complications, such as stump appendicitis. [6] The average stump lengths reported in the literature ranged from $0.5 \mathrm{~cm}$ to $6 \mathrm{~cm} \cdot{ }^{[7]} \mathrm{It}$ has been reported that it develops at variable times ( 2 months- 50 years) after appendectomy. ${ }^{[8,9]}$ In our case, stump appendicitis developed three months after the laparoscopic appendectomy and the stump length was measured as $3 \mathrm{~cm}$.

Stump appendicitis shows an acute abdomen clinic. Often, present with typical symptoms and findings of acute appendicitis, including pain that starts periumbilically and migrates to the RLQ with anorexia, nausea, and vomiting. On physical examination, there is a defense and rebound in the RLQ. WBC with neutrophil predominance and CRP levels have been reported to elevate. ${ }^{[10]}$ However, in these cases, the diagnosis is frequently overlooked because it has a history of appendectomy and this causes an increase in morbidity. Therefore, radiological imaging methods are of great importance in diagnosis. USG is the first referral imaging modality. Although it does not provide characteristic findings, it may be helpful in the differential diagnosis. On the other hand, CT is a more valuable imaging modality and it reveals the findings to be interpreted in favor of stump appendicitis, such as inflammatory changes in the pericecal area, cecal wall thickening, fluid values in the right paracolic and pericecal areas, and tubular structure related to cecum. ${ }^{[11,12]}$ In addition to this, CT not only diagnoses stump appendicitis but also helps to exclude diagnoses, such as cecal diverticulitis, that should be considered in the differential diagnosis. ${ }^{[13]}$ In our case, the symptoms, physical examination findings, and laboratory parameters were consistent with acute appendicitis. In addition, aperistaltic tubular structure, pericecal inflammatory changes, and fluid values were observed in both USG and CT, supporting stump appendicitis.

It has been reported that $68 \%$ of the stump appendicitis cases were operated due to the acute abdomen were perforated. ${ }^{[14]}$ In addition, it was reported that the duration of hospitalization was longer than that of acute appendicitis cases because the diagnosis was made later in stump 
appendicitis cases. ${ }^{[I]}$ For this reason, surgical treatment should be planned without delay in cases with stump appendicitis with imaging findings. The patient should be hydrated, appropriate antibiotherapy and complementary appendectomy should be performed. Complementary appendectomy can be performed laparoscopically or open, but open surgery should be preferred if complications such as adhesion and intraabdominal abscess are observed.

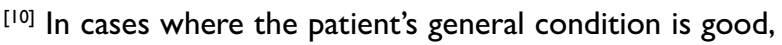
antibiotherapy and conservative treatment are among the recommendations. It has been reported that evaluating whether there is a cecal pathology with colonoscopy during conservative treatment for six weeks decreases intraoperative and postoperative morbidity. ${ }^{[15]}$ In our case, we preferred open surgery because of acute abdomen and sepsis findings and we completed complementary appendectomy without complication.

\section{CONCLUSION}

The presence of a history of appendectomy is inadequate to exclude the diagnosis of stump appendicitis in patients presenting with right lower quadrant pain and signs of peritonitis and with acute appendicitis. Although there is a rare complication, especially in patients with a history of laparoscopic appendectomy, the diagnosis should be suspicious and imaging methods should be consulted. Careful examination of the imaging findings prevents delay in diagnosis and prevents hospitalization and morbidity.

\section{Informed Consent}

Written informed consent was obtained from the patient for the publication of the case report and the accompanying images.

Peer-review

Internally peer-reviewed.

Authorship Contributions

Concept: S.A.; Design: S.A.; Supervision: S.A., M.C.Ö.; Fundings: S.A., M.C.Ö.; Materials: S.A., M.C.Ö.; Data: S.A.; Analysis: S.A.; Literature search: S.A.; Writing: S.A.; Critical revision: S.A., M.C.Ö.
Conflict of Interest

None declared.

\section{REFERENCES}

1. Vural S, Tuncay E, Onuray F, Cincic GT. Evaluation of Demographic Features of Appendectomies. South. Clin Ist Euras 2003;14(1):30-1.

2. Watkins BP, Kothari SN, Landercasper J. Stump appendicitis: case report and review. Surg Laparosc Endosc Percutan Tech 2004;14:16771. [CrossRef]

3. Subramanian A, Liang MK. A 60-year literature review of stump appendicitis: the need for a critical view. Am J Surg 2012;203:503-7.

4. Dikicier E, Altintoprak F, Ozdemir K, Gundogdu K, Uzunoglu MY, Cakmak G, et al. Stump appendicitis: a retrospective review of 3130 consecutive appendectomy cases. World J Emerg Surg 2018;13:22.

5. Devereaux DA, McDermott JP, Caushaj PF. Recurrent appendicitis following laparoscopic appendectomy. Report of a case. Dis Colon Rectum 1994;37:719-20. [CrossRef]

6. Greenberg JJ, Esposito TJ. Appendicitis after laparoscopic appendectomy: a warning. J Laparoendosc Surg 1996;6:185-7. [CrossRef]

7. Shin LK, Halpern D, Weston SR, Meiner EM, Katz DS. Prospective CT diagnosis of stump appendicitis. AJR Am J Roentgenol 2005;184:S62-S4. [CrossRef]

8. Menteș O, Zeybek N, Oysul A, Onder SC, Tufan T. Stump appendicitis, rare complication after appendectomy: report of a case. Ulus Travma Acil Cerrahi Derg 2008;14:330-2.

9. O'Leary DP, Myers E, Coyle J, Wilson I. Case report of recurrent acute appendicitis in a residual tip. Cases J 2010;3:14. [CrossRef]

10. Roberts KE, Starker LF, Duffy AJ, Bell RL, Bokhari J. Stump appendicitis: a surgeon's dilemma. JSLS 2011;15:373-8. [CrossRef]

11. Sharma M, Agrawal A. Pictorial essay: CT scan of appendicitis and its mimics causing right lower quadrant pain. Indian J Radiol Imaging 2008;18:80-9. [CrossRef]

12. Truty MJ, Stulak JM, Utter PA, Solberg JJ, Degnim AC. Appendicitis after appendectomy. Arch Surg 2008;143:413-5. [CrossRef]

13. Uludag M, Isgor A, Basak M. Stump appendicitis is a rare delayed complication of appendectomy: A case report. World J Gastroenterol 2006;12:5401-3. [CrossRef]

14. Liang MK, Lo HG, Marks JL. Stump appendicitis: a comprehensive review of literature. Am Surg 2006;72:162-6.

15. Hansson J, Körner U, Ludwigs K, Johnsson E, Jönsson C, Lundholm $\mathrm{K}$. Antibiotics as first-line therapy for acute appendicitis: evidence for a change in clinical practice. World J Surg 2012;36:2028-36. [CrossRef]

\section{Nadir Bir Akut Karın Nedeni: Laparoskopik Apendektomi Sonrası Gelişen Güdük Apandisit}

Güdük apandisit inkomplet apendektomi sonrası geriye kalan apendiksin enflamasyonu sonrası görülen nadir bir komplikasyondur. Apendektomi öyküsü olan ve akut karın tablosu ile başvuran olgularda güdük apandisit tanısı sıklıkla gözden kaçmaktadır. Görüntüleme yöntemleri tanıda büyük önem taşımaktadır. Biz bu olgu sunumumuzda iki gündür devam eden sağ alt kadran ağrısı ile acil servise başvuran ve üç ay önce laparoskopik apendektomi öyküsü olan güdük apandisit olgusunun görüntüleme ve operasyon bulgularını sunmayı amaçladık. Hasta, yapılan güdük apendektomi sonrasında sorunsuz taburcu edilmiştir.

Anahtar Sözcükler: Akut karın; apendektomi; güdük apandisit. 